This item is the archived peer-reviewed author-version of:

The first one wins : distilling the primacy effect

\title{
Reference:
}

Van Erkel Patrick, Thijssen Peter.- The first one wins : distilling the primacy effect

Eectoral studies - ISSN 0261-3794 - 44(2016), p. 245-254

Full text (Publisher's DOI): https://doi.org/10.1016/J.ELECTSTUD.2016.09.002

To cite this reference: https://hdl.handle.net/10067/1352350151162165141 


\section{The first one wins: distilling the primacy effect}

\section{Patrick F.A. van Erkel ${ }^{1}$ \& Peter Thijssen ${ }^{2}$}

Research has shown that in proportional, flexible list systems, ballot list position influences electoral success. In this paper we investigate to what extent this is due to the primacy effect, a psychological bias towards the first option in a list. We also examine alternative explanations such as the electoral beneficial traits these candidates share and extra media coverage they receive. Using data from the 2014 Belgian elections, we find that candidates with higher ballot list positions indeed score better because they have more political experience and receive more media attention. We also find strong evidence for the primacy effect which is caused by a confirmation bias as well as ballot list position being the easiest heuristic for voters.

Keywords: Preferential voting, primacy effect, political candidates, media, campaigns

This work was supported by the Research Foundation Flanders under grant number G026513N.

1. Patrick F.A. van Erkel (Corresponding author); Department of Political Science, University of Antwerp. patrick.vanerkel@uantwerpen.be; Sint-Jacobstraat 2-4, S.LN 55.116, 2000 Antwerp, Belgium.

2. Peter Thijssen; Department of Political Science, University of Antwerp. peter.thijssen@uantwerpen.be; Sint-Jacobstraat 2-4, S.LN 55.117, 2000 Antwerp, Belgium. 


\section{Introduction}

When people are presented a list with ordered items, they will disproportionally select the first option. This bias towards the first object considered in a set, which is also known as the primacy effect, has been identified in marketing research studies (Drèze et al., 1994), in multiple-choice knowledge tests (Cronbach, 1950; Mathews, 1927) and in surveys (Dillman et al., 2009). Evidence also suggests that the primacy effect influences the outcome of elections (Bain \& Hecock, 1957; Brockington, 2003; Koppell \& Steen, 2004; Lijphart \& Pintor, 1988; Miller \& Krosnick, 1998). During elections, a name-order effect takes place, meaning that the first candidate on the ballot list disproportionally benefits from this position, especially when voters have limited information about individual candidates. However, this electoral primacy effect has mainly been studied in single-member districts (Brockington, 2003; Koppell \& Steen, 2004).

Recently, a number of studies have questioned whether a primacy effect might also be found in the intra-party electoral competition that exists in many proportional systems in Western Europe (Faas \& Schoen, 2006; Lutz, 2010; Marcinkiewicz, 2013). In many Western European countries, voters must cast a vote for a political party, but in a second step have the choice or are obliged to cast a vote for a specific candidate within that party (i.e. an intra-party preferential vote). These preferential votes are important as they play a role in determining which candidates get elected and therefore influence the composition of parliament (Katz, 2003). Moreover, preferential votes can be seen as a resource which may help individual politicians to obtain more visual legislative or executive mandates, get a better ballot list position in subsequent elections or gain a more central position in the next campaign (André et al., 2015; De Winter, 1988). Research has shown that a candidate's position on the ballot list is one of the most important factors explaining individual success. The higher a candidate's position, the more preferential votes a candidate receives (Geys \& Heyndels, 2003; Miller \& Krosnick, 1998). However, while it has been proven that ballot list position matters, the mechanisms behind this effect remain unclear. On the one hand, voters may be inclined to vote for higher positioned candidates because they often have the most political experience, the 
greatest means to invest in their campaign and get the most media coverage. In these cases, voters rationally evaluate candidates and actually vote for the candidate they prefer. However, it may also be due to the primacy effect. Citizens may be biased towards the first position on the list, just because it is the first position, and therefore vote for the highest rank politician irrespective of his or her qualities.

This study focuses on the Belgian elections of 2014 and examines the extent to which the electoral success of high positioned candidates was due to their internal and external characteristics and to what extent it was due to the primacy effect. Thus, we aim to complement previous studies that have also examined the primacy effect in proportional systems but have not always been sufficiently able to separate this primacy effect from other alternative explanations. Furthermore, many studies have used the primacy effect too much as a container concept, both theoretically and empirically. While they have found evidence that candidates at the top of the list win more votes, regardless of other characteristics, the cognitive decisions and mechanisms behind this bias have remained undertheorized and understudied. The bias could exist because voters use a cost-reducing strategy and therefore opt for the first option as the simplest heuristic. Alternatively, voters may start at the top of the list when evaluating candidates, which benefits those with a higher rank.

Studying the primacy effect is important from a democratic point of view. In an age of self-responsibility, where individual politicians hold themselves more or less exclusively responsible for their electoral success, the primacy effect may create a false notion of democratic legitimacy. It may also set in motion a self-fulfilling presidentialization logic to the extent that the individual self-responsibility claims are endorsed by the party by giving electorally successful politicians more visibility and budget in future campaigns. Consequently, it is the first on the list who becomes president and not the other way around.

The primacy effect is especially challenging in contexts where there is a trend of (proposed) electoral reforms to give more weight to preferential votes. For example Bulgaria introduced preferential voting in 2011, while Belgium gave more weight to preferential votes in 
the composition of parliament (Thijssen, 2013). Also, in the Netherlands, a large citizen forum advised electoral reforms by abolishing the threshold for individual candidates to give voters more influence on which candidates are elected. These reforms are done under the assumption that citizens attach importance to showing their preference for politicians within a party. Yet if we find that many voters are guided by a primacy effect, we have to rethink these assumptions. The existence of a pure primacy effect indicates that many citizens are guided by non-substantial factors when casting a preferential vote. This implies that a large part of the preferential votes are non-preferential just as Converse (1964) claimed that for many citizens political attitudes are non-attitudes. It also suggests that political parties still have the most leverage over who gets elected, as they determine the order of the ballot list. It is therefore important to distil the primacy effect to find out which part of the bonus of higher positioned candidates is substantial and which part is unsubstantial.

\section{The primacy effect}

There are a number of reasons why a high position on a ballot list may increase a candidate's electoral success. To some extent, this is related to specific characteristics of the candidates at the top of the list, as parties are inclined to give higher positions to contenders who are likely to attract many votes (Lutz, 2010), a point we return to later. However, standing at the top of a list might also have an influence in itself due to the primacy effect. When casting a vote, citizens use different heuristics to reach a decision. For example, when voting for a political party, or when voting for a candidate in 'first past the post' systems, many citizens base their decision on a party or candidate's ideology. However, ideology becomes less important when one has to choose between candidates on the same list in a multi-party system. Of course, candidates differ somewhat in their ideological stances, but this variation is limited in comparison to the more outspoken differences between parties. Consequently, citizens have to rely on other cues. Ideally, they would base their vote on the evaluation of a candidate's competence and/or expertise. However, to evaluate candidates on the basis of objective criteria is cognitively 
demanding and requires information and resources. Therefore, it can be expected that many citizens rely on easier shortcuts. The most straightforward piece of information available to voters is a candidate's position on the ballot list. Some citizens may vote for the first candidate on the list simply because he or she occupies the first position, without making a rational evaluation of any other attributes. Thus, in its purest form, we can define the primacy effect as a cost-reducing strategy by citizens casting a vote for the first candidate on the ballot list simply because this candidate occupies the first position, without taking into account any other of the candidate's attributes, which would not have been given to this candidate if he or she had occupied a lower position on the ballot list.

However, while voting for the first candidate, as a cost-reducing strategy, could be one possible mechanism behind the primacy effect, it assumes that there is an inherent bias towards the first option, without any rational evaluation of it. Yet, this does not always hold true, especially when the order of the list is not randomly determined, as is the case in many countries. When political parties determine the order of a ballot list, citizens may be confident that parties position the most competent candidates first. While in this case the decision to cast a vote for higher-ranked candidates is not based on a direct rational evaluation of the actual or perceived competence of each candidate, it is based on the heuristic that if a candidate gets a good position from the party, this candidate must be qualified and competent. In other words, the primacy effect may occur because people believe that the best options are ranked highest. However, even in this case, it holds that the voter would not have selected the candidate on the first position if he or she had occupied a different position. Thus, in its purest form, we can define the primacy effect as follows: A cost-reducing strategy by citizens to cast a vote for the first candidate(s) on a ballot list simply because this candidate occupies the first position, which would not have been given to this candidate if he or she had occupied a lower position on this ballot list. Based on this definition, we formulate the following hypothesis: 
Hypothesis 1a: Regardless of other attributes, the first candidate on a list will disproportionally receive more votes than lower ranked candidates (pure primacy effect).

The abovementioned mechanisms explain why the first candidate on a list benefits from the primacy effect. Yet, we can also distinguish a different mechanism, which not only accounts for the success of the first candidate on the list, but impacts all high positioned candidates. According to Miller and Krosnick (1998) 'people tend to evaluate objects with a confirmation bias' (p. 293). When evaluating a list of options, or political candidates (in the context of elections), voters tend to look for reasons to vote for a candidate rather than for reasons not to vote for a candidate (Koriat et al., 1980). As citizens often start evaluating a list from the top, the confirmation bias, together with fatigue in the case of long lists, prevents citizens from evaluating all options, biasing voters towards the first options presented (Miller \& Krosnick, 1998). Whereas the previous mechanism explains mainly why the first candidate on the list receives more votes, this confirmation bias would also benefit other highly ranked candidates. Thus, it also gives the second-listed candidate an advantage over the third-listed candidate, who then has an advantage over the fourth-listed candidate, etc. We formulate the following hypothesis:

Hypothesis 1b: Regardless of individual attributes, the higher the position of a candidate on a ballot list, the more votes this candidate will receive (confirmation bias).

Most studies on the primacy effect focus on the United States (Bain \& Hecock, 1957; Brockington, 2003; Koppell \& Steen, 2004; Miller \& Krosnick, 1998), while little research has been conducted on this effect in the countries in West Europe with intra-party preference voting. Exceptions are Faas and Schoen (2006), Lutz (2010) and Marcinkiewicz (2013) who have studied respectively Germany, Switzerland and Poland. They have all found that a candidate's ballot list position has a substantial effect on success, giving preliminary evidence that the 
primacy effect also occurs with regard to preferential voting. However, especially Faas and Schoen (2006) and Lutz (2010) have not controlled for all the important alternative explanations that could explain the success of higher positioned candidates, such as the intensity of a candidate's campaign and media coverage. Moreover, both American and European studies have not differentiated between the two different mechanisms behind the primacy effect mentioned above.

\section{Intrinsic and extrinsic traits}

While the different mechanisms behind the primacy effect can explain why candidates with a higher ballot list position score better in elections, we can also think of alternative mechanisms. Citizens may base their vote on a direct evaluation of candidates' attributes. Parties anticipate the electoral success of candidates and are therefore inclined to give the best position to those with the best electoral potential (De Winter, 1988). Consequently, these candidates often possess certain intrinsic traits that are electorally beneficial. Often they are politicians with considerable political experience, either as a parliamentarian, minister or mayor of a big city (Gallagher \& Marsh, 1988; Put \& Maddens, 2013). As research has shown that citizens are more inclined to vote for incumbents (Cain et al., 1987; Gelman \& King, 1990; Johannes \& McAdams, 1981), this could explain why these candidates obtain more preferential votes. Candidates with a higher position on the list may also be more inclined to run an intense campaign. The reason behind this is twofold. First, it is difficult to get elected when positioned at the bottom of a list. Thus, it would be a risky investment to allocate considerable time and resources to the campaign. Second, because party resources are limited, all candidates are not supported equally. Instead, more resources are provided to higher positioned candidates, as they are their parties' figureheads. Accordingly, they get more attention in their parties' political advertisements and receive a larger portion of their budget (Lefevere \& Dandoy, 2011). In short, candidates who occupy a high position on the ballot list may share certain electorally beneficial intrinsic traits 
that allow them to win the most preferential votes, such as extensive political experience and the resources to run an intense campaign.

Hypothesis 2a: Candidates with a higher ballot list position receive more preferential votes because they share certain electoral beneficial intrinsic traits, such as more political experience or running a more intensive campaign.

We expect that especially the first candidate on the list possesses considerable political experience and will receive the lump sum of a party's campaign funds. This could explain the bonus they receive.

Hypothesis 2b: The first candidate on the list receives more preferential votes due to electoral beneficial intrinsic traits.

Alternatively, the effect of the ballot list position on electoral success could be mediated by extrinsic traits, especially media coverage. Not every politician receives equal media attention, as for some candidates it is easier to pass the news gates than it is for others. This is due to the fact that politicians differ in the extent to which they have news value. Studies on the 'news value theory' (Galtung \& Ruge, 1965; O’Neill \& Harcup, 2009) have shown that journalists use different criteria to decide who is newsworthy and who is not, with the most important criterion being power (Van Dalen, 2012; Midtbø, 2011; Tresch, 2009; Wolfsfeld, 2011). Consequently, journalists are more likely to cover incumbent candidates, such as ministers and parliamentarians, as they exert more news value. They are also more likely to cover candidates with the highest ballot list position. Different empirical studies, such as Midtbø (2011) in Norway and Van Aelst et al. (2008) in Belgium, have confirmed that the position of a candidate on the ballot list is indeed an important selection criterion for journalists. Not only are the highest ranked candidates usually experienced and powerful politicians, they also tend to have a 
more established relationship with journalists. Hence, because political parties determine the order of the ballot list and position the most important politicians at the top, ballot list position is an easy heuristic for journalists in determining who to cover in their articles. At the same time, parties also promote these top candidates the most (Lefevere and Dandoy, 2011). Accordingly, this is an extra cue for journalists to report more on them.

We expect that media coverage has a positive effect on the electoral success of a candidate (Maddens et al., 2006; Van Aelst et al., 2008) as it creates a feeling of proximity between a candidate and his electorate. Not only do voters recognise the candidate's name on the ballot list, they might also feel that they have more information to evaluate him or her. Thus, when evaluating the ballot list, voters are more likely to select a candidate they 'know', giving an advantage to candidates with more media attention.

Hypothesis 3a: The effect of the ballot list position on a candidate's electoral success is mediated by the amount of media coverage received.

We expect that the media also mediate the bonus for the first candidate on a list. Here the mediation is probably even stronger, as these candidates are the embodiment of their party and will therefore receive extra media coverage and thus a stronger bonus.

Hypothesis 3b: The bonus for the first candidate on a list is mediated by the amount of media coverage received.

Figure 1 gives a schematic overview of the different mechanisms that could be behind the success of higher positioned candidates. 


\section{The Belgian elections of 2014}

To test our hypotheses, we focus on the general elections of 2014 in Belgium. Belgium is a West European proportional system with a flexible ballot list. Parties determine the order of the ballot list beforehand, but voters can change the order of candidates on this list by casting preferential votes (Deschouwer, 2012). More specifically, voters can decide between two types of votes. Either they cast a vote for a political party, a list vote, or they cast a vote for one or more candidates belonging to the same party, a preferential vote. In theory, one could vote for all candidates (minus one) of the same political party, but in practice few voters actually cast more than one or two preferential votes. Preferential votes are used to determine how many seats each party receives, but they also influence the composition of the parliament. Candidates who receive enough preferential votes to surpass a quota get elected immediately. Other candidates can complement their pool of votes using list votes. These votes first go to the number one on the list until this candidate has enough votes to reach the quota, then to the number two, etc. Once all list votes are distributed, the last empty seats, if there are any left, go to the remaining candidates with the most preferential votes. Because new laws introduced at the beginning of the $21^{\text {st }}$ century stipulate that, instead of all list votes, only half can be used to complement the number of preferential votes, it is now more common that lower positioned candidates get elected because they receive a high amount of preferential votes.

Belgium is an interesting case for two reasons. First of all, the Belgian configuration shares many similarities with other West European systems with intra-party competition. While in some countries, such as Finland and the Netherlands, preferential voting is obliged and/or limited to one candidate, the option to both cast a list vote and to cast multiple preferential votes is quite common in European multimember districts. The option to cast a list vote instead of a preferential vote can be found in Austria, Iceland, Latvia, Luxembourg, Switzerland, Sweden and the Czech Republic. The option to cast multiple preferential votes can be found in Greece, 
Iceland, Latvia, Luxembourg, Slovakia, Switzerland and the Czech Republic. ${ }^{1}$ In this sense, the Belgian configuration combines two common features of the intra-party competition and we therefore expect that most of our findings are generalizable across similar systems in Europe. A second reason to select Belgium is that within the Belgian system, party leaders can only run for elections in one electoral district. This means that within parties there exists variation over districts regarding the popularity of the first candidate on the list. Due to this combination of multiple districts and list votes, we can control for the varying popularity of the different candidates who are placed first on the ballot list by their party. In the next section, we explain in more detail how we use these features.

Even though our study only focuses on Belgium, as it allows us to single out the different mechanisms, we expect that our results are also relevant for other systems of proportional representation. If a primacy effect is found, these results will not only hold in systems with a similar configuration, but probably also in systems with a slightly different configuration, such as Finland or the Netherlands, where voters are forced to cast a preferential votes. One could even argue that in such systems the primacy effect is more likely to occur than in systems with optional preference voting, as the less politically knowledgeable citizens, who are more likely to be affected by the primacy effect, can no longer cast a list vote (Marcinkiewicz \& Stegmaier, 2014).

\section{Data and method}

The Belgian elections of 2014 were held at three levels at the same time: at the regional (Flemish) level, at the federal level and at the European level. However, this study only focuses on the regional and federal levels, both first-order elections. Data were collected using a candidate survey. In the months before the elections, all 1435 candidates who were electable in Flanders - the Dutch-speaking part of Belgium, reflecting over $60 \%$ of the country's population -

\footnotetext{
${ }^{1}$ For an overview on the different European electoral systems see: http://www.electoralsystemchanges.eu.
} 
received an online questionnaire. ${ }^{2}$ In the end, 810 candidates (56.4\%) completed the questionnaire and filled in all relevant questions. This is a high response rate for an elite survey. With the survey we were able to gather data on the candidates' personal characteristics, political experience and campaign strategies. We complemented these data with information from official records, electoral lists and a media study. Using Chi-square tests, we examined whether our sample was representative for the whole population of candidates with regard to the amount of preferential votes obtained and the ballot list position. This turned out to be the case. Only with respect to political parties did we find that candidates from the Green party were slightly overrepresented in the sample, while candidates from the Far Right were somewhat underrepresented.

Individual electoral success is used as the dependent variable in our analysis. As we are interested in how well candidates electorally perform within a list and especially how well high positioned candidates perform compared to low positioned candidates on the same list, we use list proportions. This means that for each candidate we divide the absolute number of preferential votes by the total number of preferential votes cast for the candidate's party in a certain district. Thus, a score of .10 means that the candidate received $10 \%$ of all preferential votes that were cast for candidates of party A in district X. However, the distribution of this proportion is extremely skewed (see Figure a1, Appendix A). Most candidates score below 10\% of the votes on their party list, while there are a few candidates who score $20 \%$ or higher. This is problematic as it means that the residuals of our analysis have a non-normal distribution when we run a normal regression. Additionally, since the variable is a proportion, values are bounded to a value between 0 and 1 . To solve these two problems, a natural log transformation of the dependent variable is necessary (Marcinkiewicz, 2013; Taagepera, 2011). Figure a2 (Appendix

\footnotetext{
2 These are the effective candidates. Belgium also has a system of successors, candidates who cannot get elected directly into parliament, but who gets a seat if any of the effective candidates takes up a mandate. As these successors cannot directly get elected into parliament, we excluded them from the analysis.
} 
A) illustrates that this transformation of the dependent variable leads to residuals that are approximately normally distributed. ${ }^{3}$

We use ballot list position as our main independent variable of interest. These data were retrieved using official ballot lists. In order to distinguish the electoral bonus for the first candidate on the list (pure primacy effect) from the extra votes one receives by occupying one higher position on the list (primacy effect due to confirmation bias), we include the ballot list position as well as a dummy for the first position. Most likely, the effect of ballot list position is not linear but decreases for lower positions. For that reason we take the log of ballot list position. Additionally, we add a dummy for the last position as a control, since previous research has shown that these candidates score relatively better than other low positioned candidates (Marcinkiewicz, 2013). We also include different intrinsic characteristics of candidates. These are variables such as age, gender and ethnic background as well as political experience. In order to operationalize political experience, we use different measures; we make a distinction between legislative experience at the local level, executive experience at the local level, experience as mayor, experience in one of the three parliaments (regional, federal or European) and experience as a minister. We also include a measure for the intensity of a candidate's campaign. In the survey, candidates had to indicate for twelve campaign means and activities whether they planned to use it or not in their campaign. ${ }^{4}$ By counting the number of campaign means a candidate planned to use, we compose a campaign intensity index, running from 0 (no intense campaign) to 12 (a very intense campaign).

To measure media coverage, we gathered data using GoPress, a Belgian digital database and search mechanism, which archives all newspapers. For each candidate, we counted the number of newspaper articles in which they were mentioned during the campaign,

\footnotetext{
${ }^{3}$ An alternative way to account for the natural limits of the dependent variable, due to its proportional nature, would be to assume a beta distribution of the errors. For that reason we also ran our models with beta regressions (Table B1, Appendix B). The outcomes are very similar to the model where the dependent variable is logarithmically transformed. In the end, we chose the log-lin model, as beta coefficients do not sufficiently tackle the problem of the extremely skewed distribution of the dependent variable.

${ }^{4}$ These campaign means are leaflets, cards, posters, advertisements, websites, emails, Facebook and Twitter. The activities are contacting voters by telephone, campaigning in local associations, campaigning at markets and doing door-to-door visits.
} 
operationalized as the month before the elections. We included eight paid Flemish newspapers and the free daily Metro. ${ }^{5}$ We are aware that while the ballot list position influences media coverage, there might also be an effect of media coverage on the ballot list position. To control for this endogeneity, we add a separate variable that measures the media attention of the candidate in the eleven months before the start of the campaign. By adding this measure, we can filter out the mediating effect of the media during the campaign. ${ }^{6}$ Like preferential votes, media attention is unequally distributed; therefore, we also logarithmically transform the media variables.

Because the effect of media coverage might not be linear, we add an extra dummy for candidates who appeared in more than 15 newspaper articles during the campaign. We expect that once candidates pass a certain threshold, they appear to be all over the campaign and this perceived omnipresence will catalyze the effect of media coverage. We opt for a threshold of 15 news articles, since only $5 \%$ of the candidates were covered in more than 15 articles. $^{7}$

As the different candidates are nested in political parties, electoral districts and type of elections (regional or federal), we add dummies for the district and election in which each candidate was competing. By adding these fixed effects, we indirectly control for factors that matter at the district level, such as constituency size. To account for the data structure in which candidates are nested in a party list as well, we use clustered-robust standard errors. This way, we control for the fact that the score of a candidate is dependent on the score of other candidates on the same list (Marcinkiewicz, 2013). Finally, to make sure that we distil the pure primacy effect and that our results are not driven by a few top politicians who are extremely popular and ranked first on the list, we add the percentage of votes for the party list that were list votes. The percentage of list votes that are being cast for a political party in a district are

\footnotetext{
5 These newspapers are the broadsheets De Morgen, De Standaard and De Tijd, the popular newspapers Het Laatste Nieuws and Het Nieuwsblad, and the regionally oriented newspapers Het Belang van Limburg, Krant van West-Vlaanderen and Gazet van Antwerpen. ${ }^{6}$ While media attention during the election campaign is somewhat correlated to media attention before the election, VIF scores are acceptable and never exceed 3, indicating that there are no multicollinearity problems.

${ }^{7}$ As a robustness test we also checked what happens when using a threshold of 20 newspaper articles. We found similar results.
} 
influenced by 1) party factors and 2) the popularity of the first candidate on the list. By centring the percentage of list votes on the party mean across the different districts, we filter out all the party factors, leaving us with an indirect measure of the first candidate's popularity. ${ }^{8}$ Thus, a higher score means that more list votes were cast than average for this party, indicating that an unpopular candidate was placed on the first position. The reverse is true for very popular candidates, such as Bart De Wever, president of the Regionalist party that won the election, where we see that the percentage of list votes cast was far below the party average. Thus, by including this measure we can control for the popularity of some top candidates, who might otherwise bias our results. The independent variables are introduced in a number of nested models. We start with a model that only includes the different measures of the ballot list position, together with the controls. Subsequently, we add the different intrinsic characteristics of the candidates, followed by a model that includes media coverage. Respondents with missing values are deleted listwise. The final $\mathrm{N}$ is therefore 810 .

\section{Results}

Before we discuss the results of the regression analyses, it is useful to first concentrate on the distribution of the key variables. Table a1 and a2 (Appendix A) depict the descriptives for the different controls, as well as an overview of the distribution of media attention and show that candidates receive on average 7647 preferential votes. However, the high standard deviation of 15814 votes indicates that there are large differences in the success rates of the candidates. Table a1 also illustrates that most candidates have at least some political experience at the local level (over 60\%). Candidates with legislative or executive mandates at the national level are more rare (about 10\%). There are also strong differences in media attention. While, on average candidates are mentioned in six articles during the campaign period, we find that more than half

\footnotetext{
${ }^{8}$ Of course this assumes that the proportion of list votes is mostly driven by the candidate on the first position and not by other candidates on the list. We can test this by regressing the percentage of list votes on individual success, adding an interaction with the first position on the list. We find indeed that the less list votes being cast, the more success the first candidate on the list has. This indicates that the assumption holds.
} 
of the candidates (55\%) do not receive any mentions at all. Moreover, less than $3 \%$ is mentioned in more than 50 newspaper articles. This unequal distribution in media coverage could be an important explanation behind the ballot list position effect, as it may be the extra media coverage which could explain the success of top positions.

[Table 1 about here]

In Table 1, we present the regression analyses. In the first model, we run a model with only ballot list position, dummies for the first and last position, and fixed effects for the different electoral districts. This model serves as a benchmark for the subsequent models in which we add respectively the intrinsic characteristics of candidates (to test hypotheses $2 \mathrm{a}$ and $2 \mathrm{~b}$ ) and media coverage (to test hypotheses $3 \mathrm{a}$ and $3 \mathrm{~b}$ ). We can then compare the final model in which we add all these variables with the benchmark model. If we still find an effect of ballot list position and the first candidate on the list, it means we find support for hypotheses $1 \mathrm{a}$ and $1 \mathrm{~b}$.

The first model illustrates a significant influence of the ballot list position on the proportion of preferential votes. First of all, there is a strong bonus for the first candidate on the list. When a candidate occupies the first position on the ballot list, the proportion of preferential votes increases with a factor of 2.32 (95\% CI: 1.98 - 2.69). This immediately points towards the existence of a pure primacy effect, although we still need to control for alternative mechanisms in order to really draw conclusions about the first hypothesis. We also find preliminary evidence that candidates with a higher ballot list position profit due to a confirmation bias. The coefficient of the ballot list position reveals that once a candidate moves up one decile on the ballot list, the proportion of preferential votes increases by $4.9 \%$ (95\% CI: $4.4 \%-5.4 \%) .{ }^{9}$ This is a substantial effect. Based on the first model, we thus find preliminary evidence for hypothesis $1 \mathrm{a}$ and $1 \mathrm{~b}$, although we do not yet control for intrinsic and extrinsic characteristics. Note that model 1 also demonstrates a strong bonus for the last candidate on the list. However, we want to stress that

${ }^{9} e^{\left(\log \left(\frac{100+10}{100}\right)\right) \cdot 500}$ 
this indicates only that this candidate receives more votes than we would expect based on the low position, not that he or she receives more votes than candidates with a top position on the list. Finally, the R-square reveals that by just adding the different measures of ballot list position, we can already explain $83 \%$ of the variance in the list proportions of preferential votes for each candidate. This indicates that the position on the ballot list is a strong predictor of individual electoral success.

In the second model, we add intrinsic characteristics of candidates in order to test the second hypothesis, which states that certain electoral beneficial intrinsic traits, such as more political experience or running a more intensive campaign, mediate the effect of ballot list position. This model illustrates that a number of these intrinsic characteristics have a positive significant impact on electoral success. With regard to social-demographic factors, we find that ceteris paribus, women and candidates with an ethnic minority background attract more votes. Yet, no effect is found for age. We also find support for the incumbency effect. Candidates with more political experience score better during elections. This is mostly true for national representative political functions, e.g. parliamentarians. Interestingly, we find no independent effect of campaigning. Model 2 reveals no indication that candidates who use a broader range of campaign means will indeed score more votes. In other words, at least in the context of the intraparty competition, campaigning does not matter. However, we should note that we only take into account the number of campaign means that are used and that we do not take into account different strategies, such as party-centred versus personalized campaign strategies (Zittel \& Gschwend, 2008).

[Table 2 about here]

The question is whether these intrinsic characteristics, and especially political experience, mediate the ballot list position effect, as stated in hypothesis 2 . If we focus on the coefficients of the ballot list indicators, we see that this is the case. Adding the different factors to our model 
confounds $8.8 \%$ of the effect of the ballot list position in general and $6.9 \%$ of the bonus for the first candidate on the list. Of course in order to really support hypothesis 2 and conclude that intrinsic characteristics confound the ballot list position effect, we also have to assure that list pullers or candidates with a higher ballot list position are indeed more likely to have political experience. Table 2, in which we present a number of logistic regressions with the different political functions as dependent variable, illustrates that this is indeed the case. The table reveals that the higher the list position, the more likely it is that one has experience as a parliamentarian. Additionally, for the first position on the list we find that that these candidates are more likely to have experience as minister. To test the mediation more formally, we conduct Sobel-Goodman tests (Goodman, 1960; Sobel, 1982). ${ }^{10}$ These tests confirm the previous picture and show that the ballot list position effect, as well as the extra bonus for being first on the list, are significantly $(\mathrm{p}<.05)$ mediated by political experience. Thus, part of high positioned candidates' success is due to the fact that they are more often MP's or ministers. This supports the second hypothesis. Nevertheless, even after controlling for this, there is still a substantial effect left of the different ballot list position indicators.

In model 3, we add media coverage to the model to test the third hypothesis, which states that part of higher positioned candidates' success is due to the extra media attention they receive. The results of this model indicate that even when we control for media coverage in the months before the campaign, media attention during the campaign period significantly affects one's individual electoral success. Candidates who get more coverage in the media receive more preferential votes. More specifically, for every increase of $10 \%$ in media coverage, the proportion of preferential votes increases by $0.1 \%$ (95\% CI: .05\% - .2\%). ${ }^{11}$ While this may seem low at first instance, it can be quite impactful, as it means that a candidate who gets covered in five articles scores 5\% more preferential votes than his fellow party member who gets

\footnotetext{
10 To account for the dichotomous nature of some of our mediating variables, we used a spreadsheet developed by Nathaniel R. Herr, which can be found at: http://www.nrhpsych.com/mediation/logmed.html\#tools. The values for the Sobel-Goodman test were calculated using a tool developed by Kristopher Preacher and Geoffrey Leonardelli, which can be found at: http://quantpsy.org/sobel/sobel.htm. $11 e^{\left(\log \left(\frac{100+10}{100}\right)\right) \cdot 0.014}$
} 
mentioned only once. Moreover, as expected, there is an additional electoral bonus for candidates mentioned in more than 15 articles. In line with hypothesis 3, we also find that when we add media coverage to our model, the effects of the indicators for ballot list position decrease. The effect of the ballot list position is confounded by $5.3 \%$ compared to model 2 , while the bonus for the list puller is confounded by $19.8 \%$. This indicates that especially the extra electoral bonus for the first candidate is due to the fact that these candidates get more attention in the media. We confirmed this with Sobel-Goodman tests, which show that the mediation of the effect of the ballot list position by media coverage is significant, while the effect of being the first candidate on the list is significantly mediated both by media attention and the dummy for being covered in more than 15 articles. These findings support hypothesis $3 \mathrm{a}$ and hypothesis $3 \mathrm{~b}$.

Based on the three models, we thus find support for hypothesis 2 and 3. Both intrinsic traits, in particular political experience, and extrinsic characteristics such as media coverage can explain why candidates with a higher ballot list position are more successful. When we compare baseline model 1 with model 3 , in which we add the different intrinsic and extrinsic characteristics, we find that the effect of the ballot list position itself is in total confounded by $13.4 \%$ and the bonus for the list puller is confounded by $25.4 \%$. Nevertheless, even after controlling for these different characteristics, there is still a substantial effect of the ballot list position left. We argue that, considering that we controlled for all other mechanisms, the effect that is left most likely reflects the primacy effect. This supports hypothesis $1 \mathrm{a}$ and $1 \mathrm{~b}$. The fact that we find support for both hypothesis $1 \mathrm{a}$ and $1 \mathrm{~b}$ indicates the existence both of a pure primacy effect, as well as a confirmation bias when casting a vote at the ballot.

However, we should take into account that some candidates who are ranked first are party presidents who enjoy significant overall popularity. Party presidents might often be seen as the embodiments of their party, and, for that reason generate extra votes, as they are the first candidates who come to mind when thinking about that party. Normally, the factors that are included in our model should already control for this popularity. Nevertheless to be sure, we run a robustness check in model 4 in which we omit these party presidents. The fact that the results 
remain similar indicates that our results are not idiosyncratic in the sense that they are dependent on a specific configuration of extremely popular top politicians.

[Table 3 about here]

Finally, we should note that the results in this paper are only based on one election. We should therefore test whether similar patterns can be found in other elections. Unfortunately, we lack precise data for these other elections. Especially information on media attention and campaign intensity are difficult to gather. Nevertheless, we can test the robustness of our findings in two ways. First of all, we replicate model 1 for a number of Belgian federal and regional elections both in Flanders and Wallonia. This way we test whether similar trends appear with regard to the different indicators of ballot list position. Table 3 illustrates that this is the case. In all recent elections, both in Flanders and Wallonia, and both at the regional and at the federal level, candidates with a higher ballot list position receive more votes and that there. Furthermore, there is an additional bonus for the first candidate on the list. The size of the coefficients remains very similar over time. As a second test, we replicate all our models for the 2012 local elections in Antwerp. An almost identical candidate survey to the one in 2014 is available for these elections and therefore we have information on the candidates' level of political experience and on their campaign strategy. Also, the Gopress database was used to gather information about their media coverage. Table 4 demonstrates the results of the replication. Our results are very similar to Table 2. Just like for the 2014 elections, we find that having a higher ballot list position leads to more votes, with an extra bonus for the first candidate on the list. In line with hypothesis 2 and 3, these effects are confounded by political experience (ballot list position: 5.7\%; first candidate on the list: 8.5\%), as well as media attention (ballot list position: $11.2 \%$; first candidate on the list: $13.2 \%)$. Nevertheless, even after controlling for these different characteristics, there is still a substantial effect of the ballot list position left, supporting 
hypothesis $1 \mathrm{a}$ and $1 \mathrm{~b}$. These analyses show that our results are robust across different Belgian elections.

[Table 4 about here]

\section{Conclusion and discussion}

Empirical research has shown that a candidate's ballot list position is one of the crucial factors that explain individual electoral success; however, we previously lacked precise knowledge about the mechanisms underlying this effect. One possible mechanism is the primacy effect, the bias of voters towards the first option of a presented list. Alternatively, highly positioned candidates may benefit because they share certain electorally favourable intrinsic characteristics, such as more political experience, or more resources to run an intense campaign. These candidates may also receive more media coverage and for that reason have more success in obtaining preferential votes. The aim of this study was to disentangle these different mechanisms in order to distil the primacy effect. Moreover, by distinguishing different mechanisms behind the primacy effect, separating the confirmation bias from the pure primacy effect, we aimed to open the black box of this effect, both theoretically and empirically.

We reach three conclusions. First of all, we found that part of the success of higher ranked candidates can be explained by the media coverage these candidates receive. As candidates at the top of the ballot list are more likely to have some power, the media is more keen to cover them, resulting in more media attention. This creates more name recognition and increases their chance of electoral success.

Second, we found that intrinsic characteristics of high positioned candidates explain part of their success. Yet, contrary to our findings, it is not campaign intensity that explains the success of high positioned candidates. Instead, we found that especially political experience is an important factor. Candidates with a higher ballot list position are often parliamentarians with more political experience than their lower positioned peers. Thus, to some extent their success can be explained by a full rational evaluation of their intrinsic traits by citizens. 
Finally, and most importantly, we found support for the existence of a primacy effect in the context of proportional systems. Even when taking into account alternative mechanisms, our study demonstrates that citizens are more likely to cast a vote for candidates who occupy the first position on the ballot list. We found two mechanisms behind the primacy effect. First, voters have a confirmation bias when they evaluate a list. This also explains why the number two benefits over the number three, who in turn benefits over the number four. Additionally, we found a pure primacy effect. Some citizens vote for the first candidate on the list simply because he or she occupies the first position, without further evaluation of any other attributes.

One of the limitations of this study is that it only focuses on Belgium. For future research we should therefore investigate whether the primacy effect also exists in other proportional systems. However, as explained earlier we expect this to be the case. The Belgian electoral system shares several features with many other countries with intra-party preference voting, such as the option to cast a list vote. Moreover, it is even more likely that a primacy effect will be found in a system with obligatory preference voting, as citizens with the least political knowledge and thus the most sensitivity to the primacy effect cannot cast a list vote. Nevertheless, comparative studies that investigate how specific electoral rules impact preference voting are necessary.

A second limitation of this study is that it is unable to dissect the primacy effect even further. As said before, we use a broad conceptualization of the primacy effect in this paper. We argue that we can speak of a primacy effect when citizens simply vote for this candidate, because it is the easiest choice, as well as when they vote for the first candidate for reasons of indirect rationality, namely the idea that the party gave a good position to these candidates and for that reason must be competent. For future research, it would be interesting to disentangle these different options even further using experimental studies.

This study's findings have strong democratic implications. First, they show that there are often no rational motivations behind preference voting. The success of high positioned candidates, who win most of the preferential votes, can for almost $75 \%$ be explained purely by 
non-substantive factors, meaning that the vote for the first spot on the ballot list would also have been cast if that position would have been occupied by a different candidate. This is relevant considering that politicians often hold themselves more or less exclusively responsible for electoral success, a logic that is frequently followed by the party when determining who gets what position on the ballot list after the election. Second, although many commentators and researchers argue that we live in a an 'age of personalization' in which politicians have become more important at the expense of the political party (Karvonen, 2010; Mcallister, 2009), this study demonstrates that the order of the ballot list is a strong determinant of a candidate's success. As in many West European countries, the political party composes the ballot list, we can conclude that parties still have an important influence over which politician will be successful and thereby also on the composition of parliament. We should therefore be careful in declaring the demise of the role of political parties in the new age of personalization.

\section{References}

André, A., Depauw, S., Shugart, M. S., \& Chytilek, R., 2016. Party nomination strategies in flexiblelist systems Do preference votes matter? Party Politics, In Press. doi:10.1177/1354068815610974

Bain, H.M., \& Hecock, D.S., 1957. Ballot position and voter's choice. Detroit, Wayne State University Press.

Brockington, D., 2003. A Low Information Theory of Ballot Position Effect. Political Behavior 25 (1), 1-27.

Cain, B., Ferejohn, J., \& Morris, F., 1987. The personal vote. Cambridge, Harvard University Press. Converse, P.E., 1964. The nature of belief systems in mass publics. Critical Review 18, 1-74.

Cronbach, L.J., 1950. Further evidence on response sets and test design. Educational and psychological measurement 10, 3-31. 
van Dalen, A., 2012. Structural Bias in Cross-National Perspective How Political Systems and Journalism Cultures Influence Government Dominance in the News. The International Journal of Press/Politics 17 (1), 32-55. doi:10.1177/1940161211411087

DeSchouwer, K., 2012. The politics of Belgium: Governing a divided society. Basingstoke, Palgrave MacMillan.

De Winter, L., 1988. Belgium: Democracy or oligarchy? In: M. Gallagher \& Marsh, M. (Eds.), Candidate selection in comparative perspective. London, Sage, pp. 20-46.

Dillman, D.A., Smyth, J D., \& Christian, L.M., 2009. Internet, mail and Mixed-mode surveys. The tailored design method. Hoboken, John Wiley and Sons.

Drèze, X., Hoch, S.J., \& Purk, M.E., 1994. Shelf management and space elasticity. Journal of Retailing 70 (4), 301-326. doi:10.1016/0022-4359(94)90002-7

Faas, T., \& Schoen, H., 2006. The importance of being first: Effects of candidates' list positions in the 2003 Bavarian state election. Electoral Studies 25 (1), 91-102. doi:10.1016/j.electstud.2005.04.001

Gallagher, M., \& Marsh, M. (Eds.), 1988. Candidate selection in comparative perspective: The secret garden of politics. London, Sage.

Galtung, J., \& Ruge, M.H., 1965. The Structure of Foreign News The Presentation of the Congo, Cuba and Cyprus Crises in Four Norwegian Newspapers. Journal of Peace Research 2 (1), 64-90. doi:10.1177/002234336500200104

Gelman, A., \& King, G., 1990. Estimating Incumbency Advantage without Bias. American Journal of Political Science 34 (4), 1142-1164. doi:10.2307/2111475

Geys, B., \& Heyndels, B., 2003. Influence of "Cognitive Sophistication” on Ballot Layout Effects. Acta Politica, 38 (4), 295-311.

Goodman, L.A., 1960. On the Exact Variance of Products. Journal of the American Statistical Association 55 (292), 708-713. doi:10.2307/2281592 
Johannes, J.R., \& McAdams, J.C., 1981. The Congressional Incumbency Effect: Is It Casework, Policy Compatibility, or Something Else? An Examination of the 1978 Election. American Journal of Political Science 25 (3), 512-542. doi:10.2307/2110817

Karvonen, L., 2010. The Personalization of Politics: A Study of Parliamentary Democracies. Colchester, ECPR Press.

Katz, R.S., 2003. Intraparty preference voting. In: Grofman, B. \& Lijphart, A. (Eds.), Electoral laws and their political consequences. New York, Agathon Press, pp. 85-103.

Koppell, J.G.S., \& Steen, J.A., 2004. The Effects of Ballot Position on Election Outcomes. The Journal of Politics 66 (1), 267-281.

Koriat, A., Lichtenstein, S., \& Fischhoff, B., 1980. Reasons for confidence. Journal of Experimental Psychology (6), 107-118.

Lefevere, J., \& Dandoy, R., 2011. Candidate Choice in Political Advertising: What Determines Who Gets Attention? World Political Science Review, 7 (1). Retrieved from http://www.degruyter.com/view/j/wpsr.2011.7.issue-

1/wpsr.2011.7.1.1099/wpsr.2011.7.1.1099.xml

Lijphart, A., \& Pintor, R.L., 1988. Alphabetic bias in partisan elections: Patterns of voting for the Spanish Senate, 1982 and 1986. Electoral Studies 7 (3), 225-231. doi:10.1016/02613794(88)90002-9

Lutz, G., 2010. First Come, First Served: The Effect of Ballot Position on Electoral Success in Open Ballot Pr Elections. Representation 46 (2), 167-181. doi:10.1080/00344893.2010.485808

Maddens, B., Wauters, B., Noppe, J., \& Fiers, S., 2006. Effects of Campaign Spending in an Open List PR System: The 2003 Legislative Elections in Flanders/Belgium. West European Politics 29 (1), 161-168. doi:10.1080/01402380500389398

Marcinkiewicz, K., 2013. Electoral contexts that assist voter coordination: Ballot position effects in Poland. Electoral Studies 33, 322-334. 
Marcinkiewicz, K., \& Stegmaier, M., 2014. Ballot Position Effects Under Compulsory and Optional Preferential-List PR Electoral Systems. Political Behavior 37 (2), 465-486. doi:10.1007/s11109-014-9294-0

Mathews, C.O., 1927. The effect of position of printed response words upon children's answers to questions in two-response types of tests. Journal of Educational Psychology 18, 445-457.

Mcallister, I., 2009. The personalization of politics. In: Dalton, R. J. \& Klingemann, H.-D. (Eds.), The Oxford handbook of political science: The Oxford handbook of political behaviour. Oxford: Oxford University Press, pp. 571 - 588.

Midtbø, T., 2011. Explaining Media Attention for Norwegian MPs: A New Modelling Approach. Scandinavian Political Studies 34 (3), 226-249. doi:10.1111/j.1467-9477.2011.00270.x

Miller, J.M., \& Krosnick, J.A., 1998. The Impact of Candidate Name Order on Election Outcomes. The Public Opinion Quarterly 62 (3), 291-330.

O’Neill, D., \& Harcup, T., 2009. News values and selectivity. In: Wahl-Jorgensen, K. \& Hanitzsch, T. (Eds.), The handbook of journalism studies. New York and London: Routledge, pp. 161174.

Put, G.-J., \& Maddens, B., 2013. The Selection of Candidates for Eligible Positions on PR Lists: The Belgian/Flemish Federal Elections 1999-2010. Journal of Elections, Public Opinion and Parties 23 (1), 49-65. doi:10.1080/17457289.2012.743465

Sobel, M.E., 1982. Asymptotic Confidence Intervals for Indirect Effects in Structural Equation Models. Sociological Methodology 13, 290-312. doi:10.2307/270723

Taagepera, R., 2011. Adding Meaning to Regression. European Political Science 10 (1), 73-85. doi:10.1057/eps.2010.28

Tresch, A., 2009. Politicians in the Media: Determinants of Legislators' Presence and Prominence in Swiss Newspapers. The International Journal of Press/Politics 14 (1), 67-90. doi:10.1177/1940161208323266 
Van Aelst, P., Maddens, B., Noppe, J., \& Fiers, S., 2008. Politicians in the News: Media or Party Logic? Media Attention and Electoral Success in the Belgian Election Campaign of 2003. European Journal of Communication 23 (2), 193-210. doi:10.1177/0267323108089222 Wauters, B., Verlet, D., \& Ackaert, J., 2012. Giving More Weight to Preferential Votes: Welcome or Superfluous Reform? The Case of the Local Elections in Flanders (Belgium). Local Government Studies 38 (1), 91-111. doi:10.1080/03003930.2011.629193

Wolfsfeld, G. (2011). Making sense of media \& politics: Five principles in political communication. Routledge.

Zittel, T., \& Gschwend, T., 2008. Individualised Constituency Campaigns in Mixed-Member Electoral Systems: Candidates in the 2005 German Elections. West European Politics 31 (5), 978-1003. doi:10.1080/01402380802234656 


\section{Tables \& Figures}

Figure 1: A schematic overview of the "distilling process".

H3

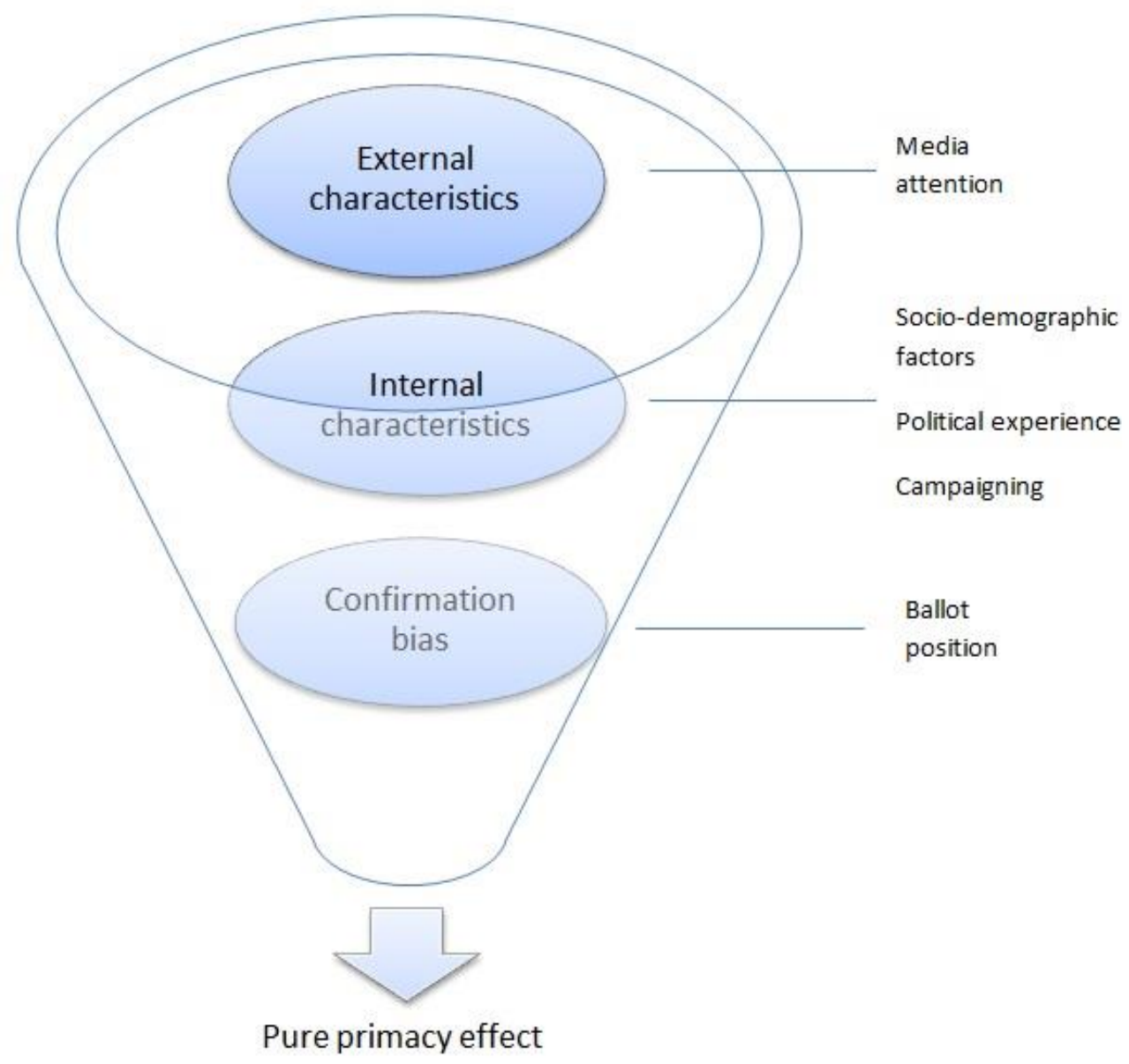


Table 1: Results of OLS regression. Fixed effects for the different electoral constituencies are not depicted. Standard errors are clustered.

\begin{tabular}{|c|c|c|c|c|}
\hline Individual electoral success & $\begin{array}{c}\text { Model } 1 \\
\text { b(SE) }\end{array}$ & $\begin{array}{c}\text { Model } 2 \\
\text { b(SE) }\end{array}$ & $\begin{array}{c}\text { Model } 3 \\
\text { b(SE) }\end{array}$ & $\begin{array}{c}\text { Model } 4 \\
\mathrm{~b}(\mathrm{SE})\end{array}$ \\
\hline \multicolumn{5}{|l|}{ Ballot list } \\
\hline First candidate on the list & $.840(.08)^{* *}$ & $.782(.09)^{* *}$ & $.627(.07)^{* *}$ & $.544(.07)^{* *}$ \\
\hline Ballot list positon(log) & $.500(.03)^{* *}$ & $.456(.03)^{* *}$ & $.433(.03)^{* *}$ & $.430(.02)^{* *}$ \\
\hline Last candidate on the list & $.775(.07)^{* *}$ & $.705(.06)^{* *}$ & $.636(.05)^{* *}$ & $.643(.05)^{* *}$ \\
\hline \multicolumn{5}{|l|}{ Inherent characteristics } \\
\hline Age & & $.000(.00)$ & $.001(.00)$ & $.001(.00)$ \\
\hline Female & & $.218(.02)^{* *}$ & $.234(.02)^{* *}$ & $.235(.02)^{* *}$ \\
\hline Ethnic minority & & $.153(.06)^{* *}$ & $.158(.05)^{* *}$ & $.167(.05)^{* *}$ \\
\hline Local council & & $.008(.03)$ & $-.020(.02)$ & $-.013(.03)$ \\
\hline Alderman & & $-.039(.03)$ & $-.056(.03)$ & $-.044(.02)$ \\
\hline Mayor & & $.109(.04)^{*}$ & $.044(.05)$ & $.048(.04)$ \\
\hline Experience Flemish parliament & & $.124(.05)^{*}$ & $.097(.05)$ & $.104(.05)^{*}$ \\
\hline Experience Federal parliament & & $.179(.06)^{* *}$ & $.122(.06)^{*}$ & $.141(.05)^{* *}$ \\
\hline Experience European parliament & & $.547(.07)^{* *}$ & $.591(.10)^{* *}$ & $.567(.07)^{* *}$ \\
\hline Minister & & $.245(.12)^{*}$ & $.011(.14)$ & $.114(.10)$ \\
\hline Campaign intensity & & $-.001(.01)$ & $-.001(.01)$ & $-.002(.00)$ \\
\hline \multicolumn{5}{|l|}{ Media } \\
\hline Media coverage(log) & & & $.014(.00)^{* *}$ & $.013(.00)^{* *}$ \\
\hline Media coverage t-1(log) & & & $.006(.00)^{*}$ & $.005(.00)$ \\
\hline$>15$ newspaper articles & & & $.361(.11)^{* *}$ & $.221(.09)^{* *}$ \\
\hline \multicolumn{5}{|l|}{ Controls } \\
\hline Federal election & $.174(.02)^{* *}$ & $.182(.02)^{* *}$ & $.185(.02)^{* *}$ & $.181(.03)^{* *}$ \\
\hline $\begin{array}{l}\text { Percentage of list votes } \\
\text { (centered on party mean) }\end{array}$ & $.009(.00)^{* *}$ & $.010(.00)^{* *}$ & $.011(.00)^{* *}$ & $.013(.00)^{* *}$ \\
\hline Constant & $2.775(.06)^{* *}$ & $-3.025(.08)^{* *}$ & $-2.998(.08) * *$ & $-3.031(.08)^{* *}$ \\
\hline $\mathbf{R}^{2}$ & .831 & .871 & .881 & .887 \\
\hline $\mathbf{N}$ & 810 & 810 & 810 & 804 \\
\hline
\end{tabular}

$* \mathrm{p}<.05 ; * * \mathrm{p}<.01$ 
Table 2: An overview of the relationship between ballot list position and respectively political experience (logistic regression models), and media coverage (OLS models). Controls and fixed effect are similar to table $3(\mathrm{~N}=810)$.

\begin{tabular}{l|c|c|c|c|c} 
& \multicolumn{1}{|c|}{$\begin{array}{c}\text { Mayor } \\
\mathbf{b}(\mathrm{SE})\end{array}$} & $\begin{array}{c}\text { Minister } \\
\mathbf{B}(\mathrm{SE})\end{array}$ & $\begin{array}{c}\text { Flemish } \\
\text { parliament } \\
\mathbf{b}(\mathrm{SE})\end{array}$ & $\begin{array}{c}\text { Experience } \\
\text { Federal } \\
\text { parliament } \\
\mathbf{b}(\mathrm{SE})\end{array}$ & $\begin{array}{c}\text { Media } \\
\text { coverage } \\
\mathbf{b}(\mathrm{SE})\end{array}$ \\
\hline $\begin{array}{l}\text { First candidate } \\
\text { on the list }\end{array}$ & $-.243(.77)$ & $3.535(1.24)^{* *}$ & $-1.793(.65)^{* *}$ & $-.663(.71)$ & $1.676(.52)^{* *}$ \\
$\begin{array}{l}\text { Ballot list } \\
\text { position(log) } \\
\begin{array}{l}\text { Last candidate on } \\
\text { the list }\end{array}\end{array}$ & $.489(.23)^{*}$ & $1.741(.72)^{*}$ & $2.584(.28)^{* *}$ & $2.594(.38)^{* *}$ & $.993(.19)^{* *}$ \\
& $.741(.72)$ & $5.369(1.31)^{* *}$ & $4.878(.72)^{* *}$ & $5.082(.76)^{* *}$ & $2.271(.62)^{* *}$
\end{tabular}

$* \mathrm{p}<.05 ; * * \mathrm{p}<.01$ 
Table 3: Robustness checks of model 1 for a number of Belgian elections.

\begin{tabular}{|c|c|c|c|c|}
\hline & $\begin{array}{c}\text { Federal } 2014 \\
\text { (Wallonia) } \\
\text { b(SE) }\end{array}$ & $\begin{array}{c}\text { Federal } 2010 \\
\text { (Wallonia and } \\
\text { Flanders) } \\
\text { B(SE) }\end{array}$ & $\begin{array}{c}\text { Federal } 2007 \\
\text { (Wallonia and } \\
\text { Flanders) } \\
\text { B(SE) }\end{array}$ & Flemish 2009 \\
\hline First candidate on the list & $.708(.10)^{* *}$ & $.680(.06)^{* *}$ & $.684(.06)^{* *}$ & $.895(.11)^{* *}$ \\
\hline Ballot list position(log) & $.570(.03)^{* *}$ & $.565(.02)^{* *}$ & $.528(.03)^{* *}$ & $.470(.04)^{* *}$ \\
\hline Last candidate on the list & $.445(.06)^{* *}$ & $.954(.07)^{* *}$ & $.857(.09)^{* *}$ & $1.060(.11)^{* *}$ \\
\hline $\begin{array}{l}\text { Percentage of list votes } \\
\text { (centered on party mean) }\end{array}$ & $.009(.00)^{* *}$ & $.006(.00)^{*}$ & $.003(.00)$ & $.006(.00)$ \\
\hline $\mathrm{R}^{2}$ & .847 & .793 & .770 & .736 \\
\hline $\mathbf{N}$ & 405 & 1025 & 950 & 708 \\
\hline
\end{tabular}

${ }^{*} \mathrm{p}<.05 ;{ }^{*} \mathrm{p}<.01$ 
Table 4: Results of the OLS regression for the district elections 2012 Antwerp. Fixed effects for the different electoral constituencies are not depicted. Standard errors are clustered.

\begin{tabular}{|c|c|c|c|}
\hline Individual electoral success & $\begin{array}{c}\text { Model } 1 \\
\text { b(SE) }\end{array}$ & $\begin{array}{c}\text { Model } 2 \\
b(S E)\end{array}$ & $\begin{array}{c}\text { Model } 3 \\
b(S E)\end{array}$ \\
\hline \multicolumn{4}{|l|}{ Ballot list } \\
\hline First candidate on the list & $1.284(.16)^{* *}$ & $1.210(.15)^{* *}$ & $1.050(.16)^{* *}$ \\
\hline Ballot list positon(log) & $.480(.04)^{* *}$ & $.439(.04)^{* *}$ & $.390(.04)^{* *}$ \\
\hline Last candidate on the list & $1.405(.27)^{* *}$ & $1.236(.25)^{* *}$ & $.879(.23)^{* *}$ \\
\hline \multicolumn{4}{|l|}{ Inherent characteristics } \\
\hline$\overline{\text { Age }}$ & & $.000(.00)$ & $.001(.00)$ \\
\hline Female & & $.043(.07)$ & $.043(.07)$ \\
\hline Ethnic minority & & $.043(.28)$ & $.048(.28)$ \\
\hline Political experience & & $.218(.06)^{* *}$ & $.146(.06)^{* *}$ \\
\hline Campaign intensity & & $.010(.01)$ & $.003(.01)$ \\
\hline \multicolumn{4}{|l|}{ Media } \\
\hline$\overline{\text { Media coverage(log) }}$ & & & $.064(.03)^{* *}$ \\
\hline Media coverage t-1 log) & & & $.025(.02)$ \\
\hline \multicolumn{4}{|l|}{ Controls } \\
\hline $\begin{array}{l}\text { Percentage of list votes } \\
\text { (centered on party mean) }\end{array}$ & $.019(.01)^{* *}$ & $.020(.01)^{* *}$ & $.021(.01)^{* *}$ \\
\hline Constant & $-2.893(.06)^{* *}$ & $-3.123(.08)^{* *}$ & $-2.896(.08)^{* *}$ \\
\hline $\mathbf{R}^{2}$ & .546 & .551 & .565 \\
\hline $\mathbf{N}$ & 358 & 358 & 358 \\
\hline
\end{tabular}




\section{Appendix A}

Figure A1: Distribution of the dependent variable before transformation.

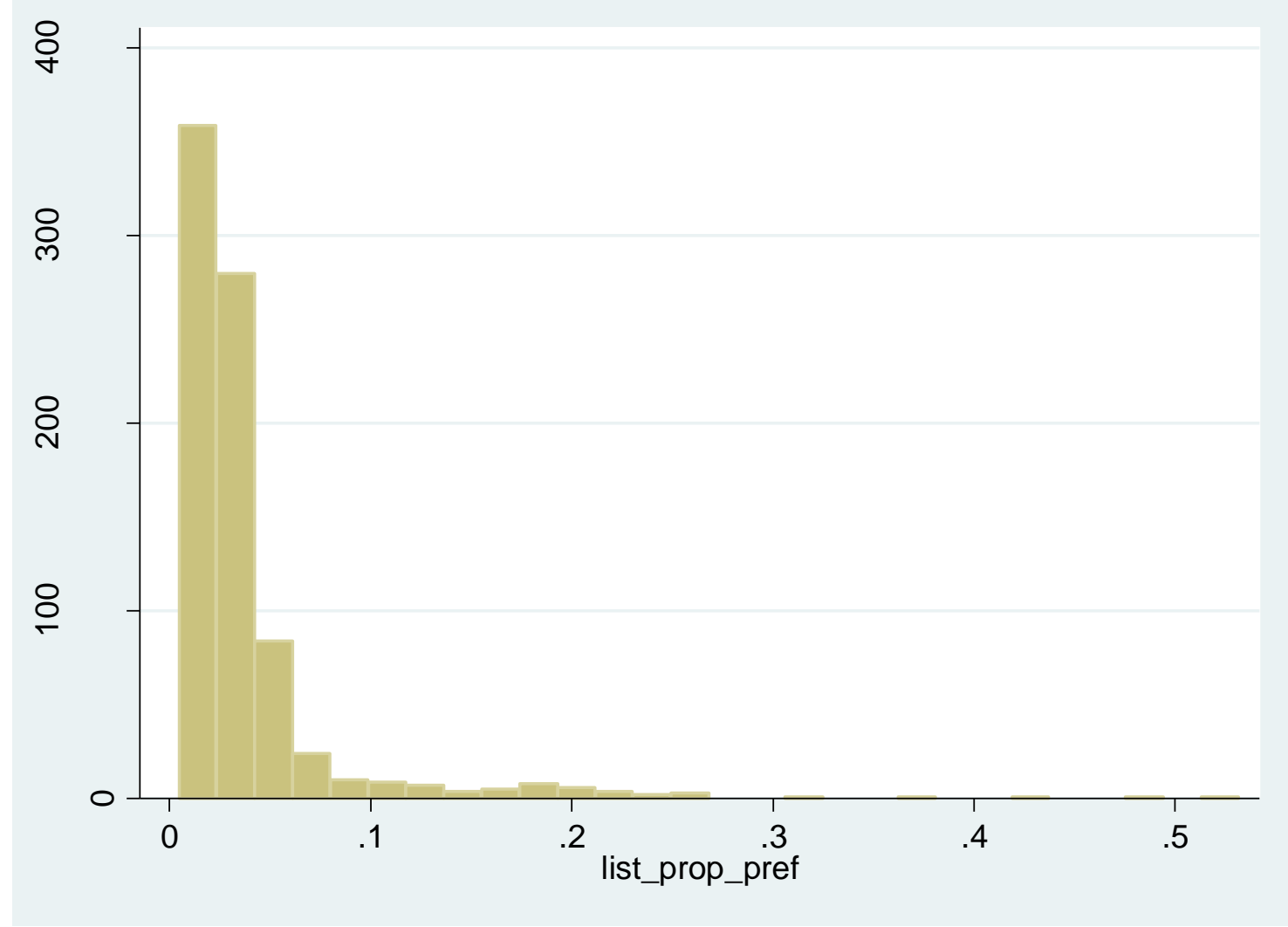

Figure A2: Distribution of the residuals after the log-lin model.

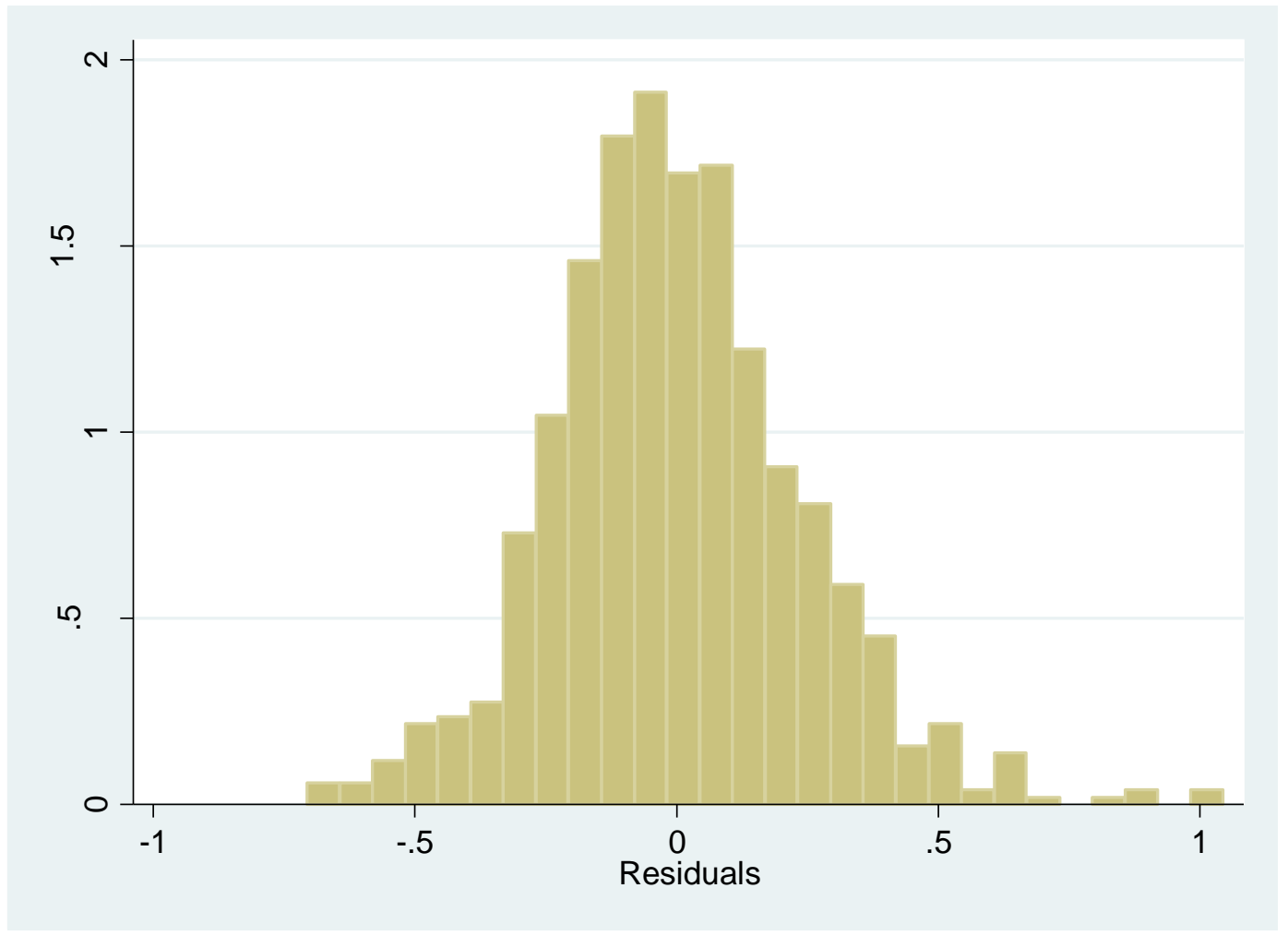


Table A1: Descriptive statistics

\begin{tabular}{|c|c|c|}
\hline & Mean (S.D) & Freq (\%) \\
\hline Number of preferential votes & $7647.47(15814.2)$ & \\
\hline Ballot list position & $11.32(7.5)$ & \\
\hline Media attention & $6.24(40.5)$ & \\
\hline Media attention $t-1$ & $65.1(286.9)$ & \\
\hline Campaign intensity & $8.09(2.1)$ & \\
\hline Age & $42.39(11.9)$ & \\
\hline \multicolumn{3}{|l|}{ Gender } \\
\hline - Male & & $373(46.05)$ \\
\hline - Female & & $437(53.95)$ \\
\hline \multicolumn{3}{|l|}{ Etnicity } \\
\hline - Belgian/European & & 761(93.95) \\
\hline - Ethnic minority & & $49(6.05)$ \\
\hline \multicolumn{3}{|l|}{ List puller } \\
\hline - Yes & & $47(5.80)$ \\
\hline$-\quad$ No & & 763(94.20) \\
\hline \multicolumn{3}{|l|}{ List pusher } \\
\hline - Yes & & $34(4.20)$ \\
\hline$-\quad$ No & & $776(95.80)$ \\
\hline \multicolumn{3}{|l|}{ Local council } \\
\hline - Yes & & $508(62.72)$ \\
\hline$-\quad$ No & & $302(37.28)$ \\
\hline \multicolumn{3}{|l|}{ Alderman } \\
\hline - Yes & & $224(27.65)$ \\
\hline$-\quad$ No & & $586(72.35)$ \\
\hline \multicolumn{3}{|l|}{ Mayor } \\
\hline - Yes & & $65(8.02)$ \\
\hline$-\quad$ No & & 745(91.98) \\
\hline \multicolumn{3}{|l|}{ Experience Flemish parliament } \\
\hline - Yes & & $65(8.02)$ \\
\hline$-\quad$ No & & 745(91.98) \\
\hline \multicolumn{3}{|l|}{ Experience Federal parliament } \\
\hline - Yes & & $76(9.38)$ \\
\hline$-\quad$ No & & $734(90.62)$ \\
\hline \multicolumn{3}{|l|}{ Experience European parliament } \\
\hline - Yes & & $3(0.37)$ \\
\hline$-\quad$ No & & $807(99.63)$ \\
\hline \multicolumn{3}{|l|}{ Minister } \\
\hline - Yes & & $20(2.47)$ \\
\hline$-\quad$ No & & 790(97.53) \\
\hline \multicolumn{3}{|l|}{ Party } \\
\hline - Greens & & 160(19.75) \\
\hline - $\quad$ Social democrats & & $103(12.72)$ \\
\hline - $\quad$ Christian democrats & & $116(14.32)$ \\
\hline - $\quad$ Regionalist party & & 131(16.17) \\
\hline - $\quad$ Liberal party & & $112(13.83)$ \\
\hline - $\quad$ Far right & & $71(8.77)$ \\
\hline - $\quad$ Socialist party & & $117(14.44)$ \\
\hline \multicolumn{3}{|l|}{ Electoral level } \\
\hline - Regional & & $464(57.28)$ \\
\hline - $\quad$ Federal & & $346(42.72)$ \\
\hline
\end{tabular}


Table A2: A distribution of media coverage

\begin{tabular}{l|c} 
Number of articles & Frequency (\%) \\
\hline 0 & $55.9 \%$ \\
$1-10$ & $37.8 \%$ \\
$11-20$ & $2.6 \%$ \\
$21-50$ & $1.1 \%$ \\
$51-100$ & $1.4 \%$ \\
$>100$ & $1.2 \%$ \\
\hline
\end{tabular}




\section{Appendix B}

Table B1: Results of the beta regression models.

\begin{tabular}{|c|c|c|c|c|}
\hline Individual electoral success & $\begin{array}{l}\text { Model } 1 \\
\text { b(SE) }\end{array}$ & $\begin{array}{c}\text { Model } 2 \\
\text { b(SE) }\end{array}$ & $\begin{array}{c}\text { Model } 3 \\
\text { b(SE) }\end{array}$ & $\begin{array}{l}\text { Model } 4 \\
\text { b(SE) }\end{array}$ \\
\hline \multicolumn{5}{|l|}{ Ballot list } \\
\hline First candidate on the list & $.945(.09)^{* *}$ & $.883(.10)^{* *}$ & $.720(.08)^{* *}$ & $.645(.07)^{* *}$ \\
\hline Ballot list positon(log) & $.515(.03)^{* *}$ & $.490(.04)^{* *}$ & $.446(.03)^{* *}$ & $.454(.02)^{* *}$ \\
\hline Last candidate on the list & $.749(.08)^{* *}$ & $.722(.07)^{* *}$ & $.614(.08)^{* *}$ & $.676(.05)^{* *}$ \\
\hline \multicolumn{5}{|l|}{ Inherent characteristics } \\
\hline Age & & $.000(.00)$ & $.001(.00)$ & $.000(.00)$ \\
\hline Female & & $.218(.03)^{* *}$ & $.249(.03)^{* *}$ & $.246(.02)^{* *}$ \\
\hline Ethnic minority & & $.084(.07)$ & $.108(.07)$ & $.158(.06)^{* *}$ \\
\hline Local council & & $-.008(.03)$ & $-.062(.04)$ & $-.035(.03)$ \\
\hline Alderman & & $-.077(.04)$ & $-.100(.04)^{* *}$ & $-.034(.03)$ \\
\hline Mayor & & $.078(.09)$ & $-.007(.08)$ & $.014(.05)$ \\
\hline Experience Flemish parliament & & $.091(.10)$ & $.046(.08)$ & $.039(.04)$ \\
\hline Experience Federal parliament & & $.181(.08)^{*}$ & $.099(.07)$ & $.123(.05)^{*}$ \\
\hline Experience European parliament & & $.507(.08)^{* *}$ & $.552(.13)^{* *}$ & $.562(.07)^{* *}$ \\
\hline Minister & & $.258(.16)$ & $.040(.17)$ & $.247(.25)^{* *}$ \\
\hline Campaign intensity & & $-.012(.02)$ & $-.018(.02)$ & $-.001(.01)$ \\
\hline \multicolumn{5}{|l|}{ Media } \\
\hline Media coverage (log) & & & $.024(.01)^{* *}$ & $.015(.00)^{* *}$ \\
\hline Media coverage t-1 (log) & & & $.014(.00)^{* *}$ & $.008(.00)^{* *}$ \\
\hline > 15 newspaper articles & & & $.349(.12)^{* *}$ & $.128(.10)^{* *}$ \\
\hline \multicolumn{5}{|l|}{ Controls } \\
\hline Federal election & $.201(.02)^{* *}$ & $.196(.03)^{* *}$ & $.202(.03)^{* *}$ & $.183(.03)^{* *}$ \\
\hline $\begin{array}{l}\text { Percentage of list votes } \\
\text { (centered on party mean) }\end{array}$ & $.002(.00)$ & $.001(.00)$ & $.003(.00)^{*}$ & $.013(.00)^{* *}$ \\
\hline Constant & $-2.593(.08)^{* *}$ & $-2.676(.17)^{* *}$ & $-2.630(16)^{* *}$ & $-2.794(.10)^{* *}$ \\
\hline $\mathbf{N}$ & 810 & 810 & 810 & 804 \\
\hline
\end{tabular}

${ }^{*} \mathrm{p}<.05 ; * * \mathrm{p}<.01$ 